Prévost A., Robert S. (2016) Local spatial planning practices in four French Mediterranean coastal territories under pressure. Land Use Policy, $56: 68-80$ https://doi.org/10.1016/j.landusepol.2016.04.034 


\title{
Local spatial planning practices in four French Mediterranean coastal territories under pressure
}

\author{
Land Use Policy (2016) 56: 68-80 \\ https://doi.org/10.1016/j.landusepol.2016.04.034
}

\begin{abstract}
a ESPACE, UMR 7300, CNRS, Aix Marseille Universite, Avignon Universite, Universite Nice Sophia-Antipolis, F-06204 Nice Cedex, France
\end{abstract}

${ }^{*}$ Corresponding author at:

ESPACE, UMR 7300, CNRS, Aix Marseille Universite, Technopole de l'Environnement Arbois Méditerranée, BP 80-13545, Aix-en-Provence Cedex 04, France. Tel. : +33 442 9085 32. Email : samuel.robert@univ-amu.fr

Email addresses of co-author:

aurelie.prevost@univ-amu.fr (A. Prevost)

\begin{abstract}
Limiting land consumption is an undisputed priority today. In France, numerous laws, regulations and space protection measures (under the town planning and environment codes) govern territorial development to protect land resources and the environment. Yet urbanization at the expense of natural and agricultural areas remains critical, particularly in coastal areas. This article proposes an analysis of spatial planning practices at local level in the French Mediterranean, considering the implementation of spatial planning over time as a marker of the will to manage urban development. After examining features specific to coastal planning legislation and regulations in France, it identifies past and present trajectories of urban planning practices and the development of environmental protection. Four French Mediterranean areas are assessed: the Marseille coast, the Gulf of Aigues-Mortes and the Corsican sites of Balagne and Biguglia.
\end{abstract}

\section{Keyword}

Urban planning; Territorial planning; Environmental protection measures; French mediterranean ; Urbanization ; Spatio-temporal analysis 


\section{Introduction}

In France, since the 1970s and the first official report on the state of the coastal zone (Piquard, 1974), there has been increasing social and political awareness of the need to protect coastal areas and to conduct spatial planning policies on the coasts. This has resulted in a national doctrine on land planning with specific provisions and recommendations in terms of coastal area development (Bouyer, 2004; Deboudt et al., 2008; Merckelbagh, 2009). Among the major outcomes relevant to coastal zone protection are the institution of the Coastal Conservancy (1975) and the Coastal Act (1986). Moreover, there is more urban planning today in coastal municipalities than in the rest of France and environmental protection measures are also more widespread on the coasts (SOeS et al., 2014). However, there has been persistent artificialization and development of coastal territories at the expense of natural and agricultural areas on all French coasts (CGDD, 2011). Between 1962 and 2010, the population of metropolitan France living by the sea increased by $41 \%$ (SOeS et al., 2014), and today most coastal areas are facing significant urban pressure related to their attractiveness (Lebahy and Le Délézir, 2006). Moreover, a significant part of the area lying in the $0-250 \mathrm{~m}$ coastal strip and not yet urbanized is not strongly protected (CGDD, 2012a). In this general context of demographic and urban pressure (CGDD, 2011), the French Mediterranean is emblematic of coasts dealing with urbanization processes over a long period of time. It is also representative of the situation pertaining in the North-Western part of the Mediterranean region (Cocossis, 1991; Cortesi, 1995; Vallega, 1995; Cori, 1999; Benoit and Comeau, 2005; Perrin, 2013). In this area, tourism and real estate are very strong drivers of change: agriculture has difficulty resisting urban expansion both along the coast and in nearby inland areas, with residential developments, resorts, transport infrastructure, leisure facilities and commercial zones. Although urbanization is progressing more slowly than a few decades ago, it is still a critical issue. Between 2000 and 2006, artificial surfaces increased by $+1.7 \%$ in the coastal municipalities of the French Mediterranean: $+3.7 \%$ in Languedoc-Roussillon region, $+1.1 \%$ in Provence Alpes Côte d'Azur and $+1.9 \%$ in Corsica (Corine Land Cover data, from SOeS-ONML, 2009). Undoubtedly, all this suggests some discrepancy between public policy and the persistence of urban sprawl, which needs to be investigated.

The objective of this paper is to trace the various local trajectories of implementation of spatial planning tools in the French Mediterranean coastal zone over the last decades. To highlight any variations among our four French Mediterranean study areas, we use a comparative approach. We analyze first, the extent 
to which the French spatial planning framework allows specific and efficient management of coastal areas and second, how the principles behind the national planning framework are applied locally. The study seeks to identify differences or common practices in the way local municipalities made use of urban planning tools over time and in their approaches to protecting natural areas.

\section{Spatial planning assessment in the coastal zone}

Although urban sprawl is not restricted to coasts (EEA, 2006a), coastal development is considered a particular challenge (Burak et al., 2004; EEA, 2006b; Catalàn et al., 2008; Levin et al., 2009; Guneroglu, 2015). Accordingly, many authors seek a better understanding of the public policies on coastal management. Some look at the quality of spatial planning practices in coastal areas (Davis, 2004; Tang, 2008, Gangai and Ramachandran, 2010), while other studies attempt to link the implementation of these policies with their actual effects over time (Capineri et al., 1995; Malvarez-Garcia et al., 2003; Conway and Lathrop, 2005; Crawford, 2007; Daligaux and Minvielle, 2010). The implementation of spatial management tools over time is indisputably a key determinant of urban sprawl in coastal zones (Dauvin et al., 2004; Deboudt et al., 2008; CGDD, 2012a; Drobenko, 2013).

In France, the spatial planning framework originates from the 1967 land planning law and has gradually evolved until recently (ALUR law, 2014). It consists of a multilevel (local, inter-municipal and supracommunal) planning system, with different planning documents designed by local authorities since the decentralization law in 1983. Although the first texts documenting the need to preserve coastal territories date from the 1970s (i.e. the Piquard Report in 1973; the Statement of August 4th, 1976 on "protection and coastal development"; the Ornano Directive of 1979), they had a relatively limited effect on spatial planning at that period (Rochette, 2007). It was only in 1983 that all territories, including coastal territories, were required to limit space consumption through planning regulations. Later, in 1986, French doctrine on coastal area management was finally established with the Coastal Act (Rochette, 2007). This law was a breakthrough in the practice of coastal urban planning, requiring every local planning document to regulate urbanization in certain types of areas: a 0-100 meter strip from the shore; areas close to the shore; outstanding natural areas (Becet 1987). In the 2000s, other regulatory mechanisms affecting coastal urbanization emerged. For instance, for certain coastal towns where large urban developments were planned, it was decided that an assessment of their planning documents would be required. 
This initiated with European Directive 2001/42/CE of 2001 and was extended in 2013 to all territories with local urban plans in the coastal zone.

Nowadays, notwithstanding certain exceptions, there are very few illegal constructions in France. The majority of new built-up areas are the result of administrative decisions, principally the building permits issued by local authorities. In coastal areas, as in the rest of the country, this authorization is subject to local planning regulations determining rights to use and build on any piece of land (i.e. authorized and unauthorized construction). Local regulations are defined in compliance with developmental provisions for larger areas and they are constrained by various environmental protection measures. Thus, any new construction is subject to the multilevel planning system. In this context, analyzing the persistent urbanization observed in the French Mediterranean coastal zone involves examining both the different land planning practices and the provisions for the protection of natural areas. As stated above, urbanization is regulated both by the French State and by local authorities, who have been particularly influential in the urban planning process since the decentralization law of 1983. It can therefore be hypothesized that local land planning practices explain the gaps between the national doctrine regarding coastal land management and the observed urbanization of coastal areas. This suggests that urbanization is the result of how a territory makes use of emerging urban planning tools and environmental protection measures (which are also a key factor for space management). Thus, the study of local land planning practices appears relevant to enhance our understanding of coastal urbanization. The history of local spatial planning in coastal territories may reveal a mismatch between local decisions and the principles behind national policy. Locally, political decisions remain a determining factor for the future of a territory, so that the use of local planning tools can be considered as a marker of the will to direct and control spontaneous dynamics.

\section{Research design and methodology}

\subsection{Study area}

In Western Europe, the Mediterranean coast of France was one of the first to experience residential development and tourism. It benefited fully from the economic and social development of the period after the Second World War, which, with increased mobility and leisure, led to massive coastal urbanization (Dagorne 1995; Cori, 1999; Zaninetti, 2006). Today, the Mediterranean coasts are a leading tourist destination: jobs in tourism-related sectors represent more than $7 \%$ of total jobs in the three regions 
bordering the Mediterranean, and Provence Alpes Côte d'Azur and Languedoc-Roussilon regions rank respectively first and third in terms of overnight stays in France (Direction Générale des Entreprises, 2014). Besides tourism, the Mediterranean coast has long hosted major port facilities with related economic activities, which have also contributed to the expansion of artificialized spaces (Meinesz et al., 1991). Toulon harbor and of course the port of Marseille, with its industrial port extension in the Gulf of Fos-sur-Mer, are landmark sites for the French economy. However, despite such strong human pressure, large areas remain natural and often preserved: the Marseille creeks, the Languedoc lagoons, the mountains and hills of Provence, vast expanses of Corsican maquis, etc. This landscape diversity, which is partly responsible for the attractiveness of these regions, provides a suitable framework for exploring the conditions of local implementation of spatial planning aimed at controlling coastal urbanization.

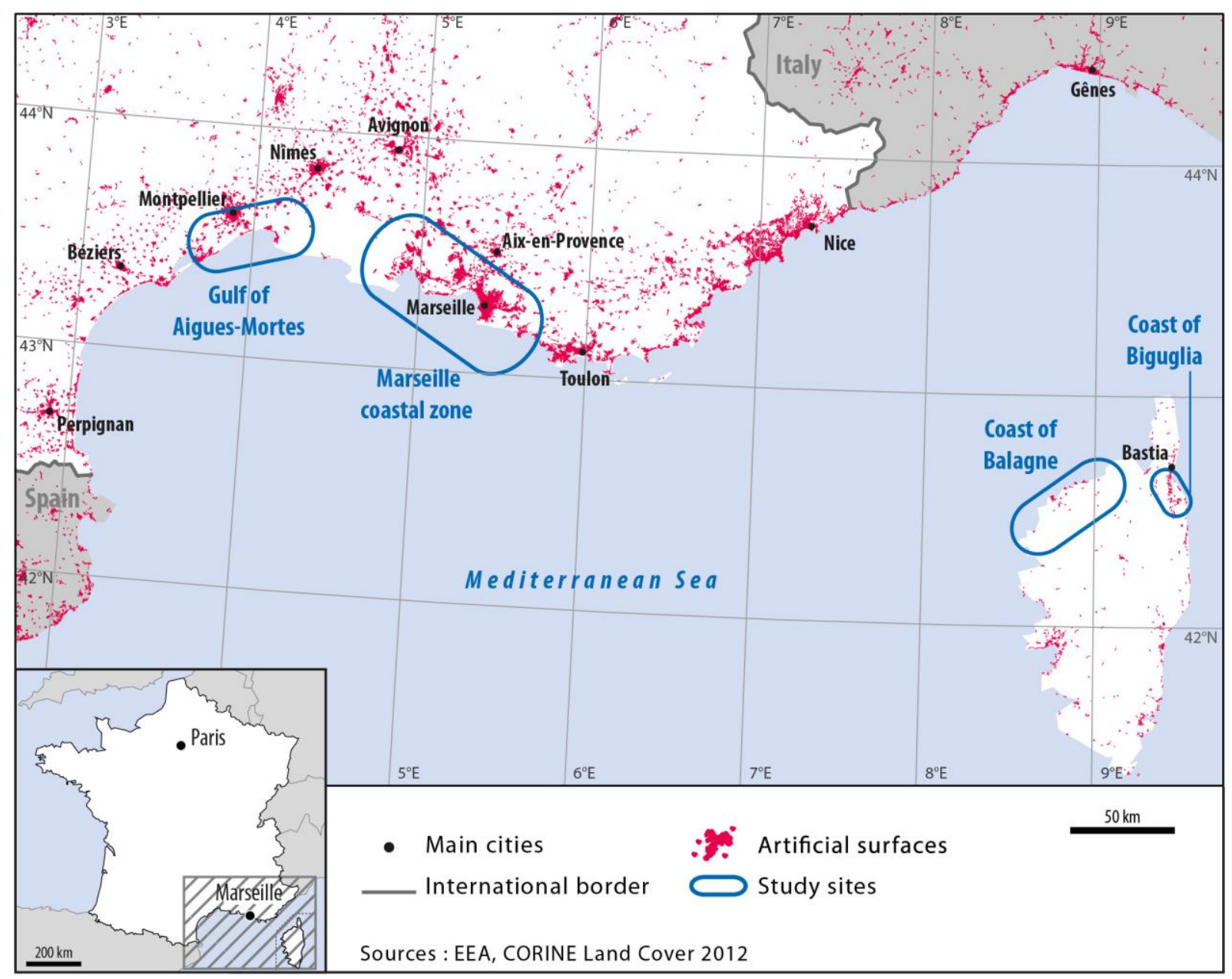

Fig. 1. Geographical location of the study areas

A comparative approach was used to identify similarities and/or differences among local territories. Fifty coastal communes as defined in the Coastal Act of January 3, 1986 (representing approximately 23\% 
of the French Mediterranean coastal towns) were selected. They belong to four study areas falling under the Mediterranean Coast Observatory project ${ }^{1}$, a Human-Environment Observatory set up by the French National Center for Scientific Research (CNRS) to promote multidisciplinary studies on coastal change and anthropogenic pressures on the coasts: the Marseille coastal zone, the Gulf of Aigues-Mortes, and the coasts of Balagne and Biguglia in Corsica (Fig. 1). These coastal areas are representative of the French Mediterranean and its diversity in terms of maritime and residential economy, built-up areas, types of natural areas (wetlands of ecological importance, sites of national interest, areas of remarkable biodiversity or with high landscape value) or institutional structures (Melot and Paoli, 2011; Douay, 2009). The fifty communes differ greatly in size and population (Table 1), and the assessment proposed in this article should shed light on how territories have used different spatial planning tools to deal with urban pressure, revealing any common practices and/or representative planning trajectories.

\begin{tabular}{|c|c|c|c|c|c|}
\hline Study area & \multicolumn{2}{|c|}{$\begin{array}{c}\text { Number of } \\
\text { communes }\end{array}$} & \multicolumn{2}{|c|}{$\begin{array}{c}\text { Municipal area (Sq km) } \\
\text { minimum/maximum }\end{array}$} & \multicolumn{2}{|c|}{$\begin{array}{c}\text { Population (2012) * } \\
\text { minimum/maximum }\end{array}$} \\
\hline $\begin{array}{c}\text { Marseille } \\
\text { coastal area }\end{array}$ & 20 & 9.9 & 238.4 & 4507 & 852,516 \\
\hline $\begin{array}{c}\text { Gulf of Aigues- } \\
\text { Mortes }\end{array}$ & 14 & 8.4 & 76.9 & 1506 & 22,728 \\
\hline $\begin{array}{c}\text { Coast of } \\
\text { Balagne }\end{array}$ & 12 & 1.7 & 184.3 & 153 & 5514 \\
\hline $\begin{array}{c}\text { Coast of } \\
\text { Biguglia }\end{array}$ & 4 & 19 & 48.3 & 4883 & 7950 \\
\hline
\end{tabular}

* INSEE, Population census, 2012.

Table 1 Diversity of the communes composing the four study sites

\subsection{Methodological framework}

The study uses epistemological references primarily from geography, following a methodology belonging to the field of quantitative geography. This consists in the quantitative processing of large volumes of space-related data to reveal and explain the organization of geographical space (Hagget, 1965; Gould, 1970; Taylor, 1977; Silk, 1979). The approach is particularly inspired by studies aimed at determining classes or categories of places / geographical objects, using classification methods in

\footnotetext{
${ }^{1}$ Human-Environment Observatory of the Mediterranean coasts : http:// www.ohm-littoral-mediterra-
} neen.fr 
conjunction with thematic mapping to reveal specific spatial characteristics as well as local or regional structures (Chuman, T. \& Romportl, D., 2010; Janßena et al., 2013; Longley et al., 2011; Swerts \& Pumain, 2013; Grandclément \& Boulay, 2015). We also borrow methods from urban planning studies, law studies and more generally from human geography, to design the research and collect relevant data (extensive field work, stakeholder interviews, use of archives).

Research (Fig. 2) was conducted in several stages. We started by analyzing the legislative and regulatory framework $(A)$, followed by a significant collection of data (B, detailed below), and ended with statistical data processing (C). Structured within ArcGIS 10.0 software, the database included sets of data on the implementation of local planning documents and the use of environmental protection measures over time (i.e. the major components of local spatial planning history). It also contained more general spatial data (administrative boundaries, land use, environmental protection zoning, etc.), enabling us construct additional variables with spatial analysis operators within the GIS and to produce thematic maps, at various stages of the research. From the database, data tables were generated for statistical processing (descriptive statistics: simple and multivariate analysis) so as to classify the 50 communes according to both urban planning data and environmental protection measures, and to map the results of these analysis. Finally, we combined the results of the two classifications to create a typology of municipalities' spatial management practices. 


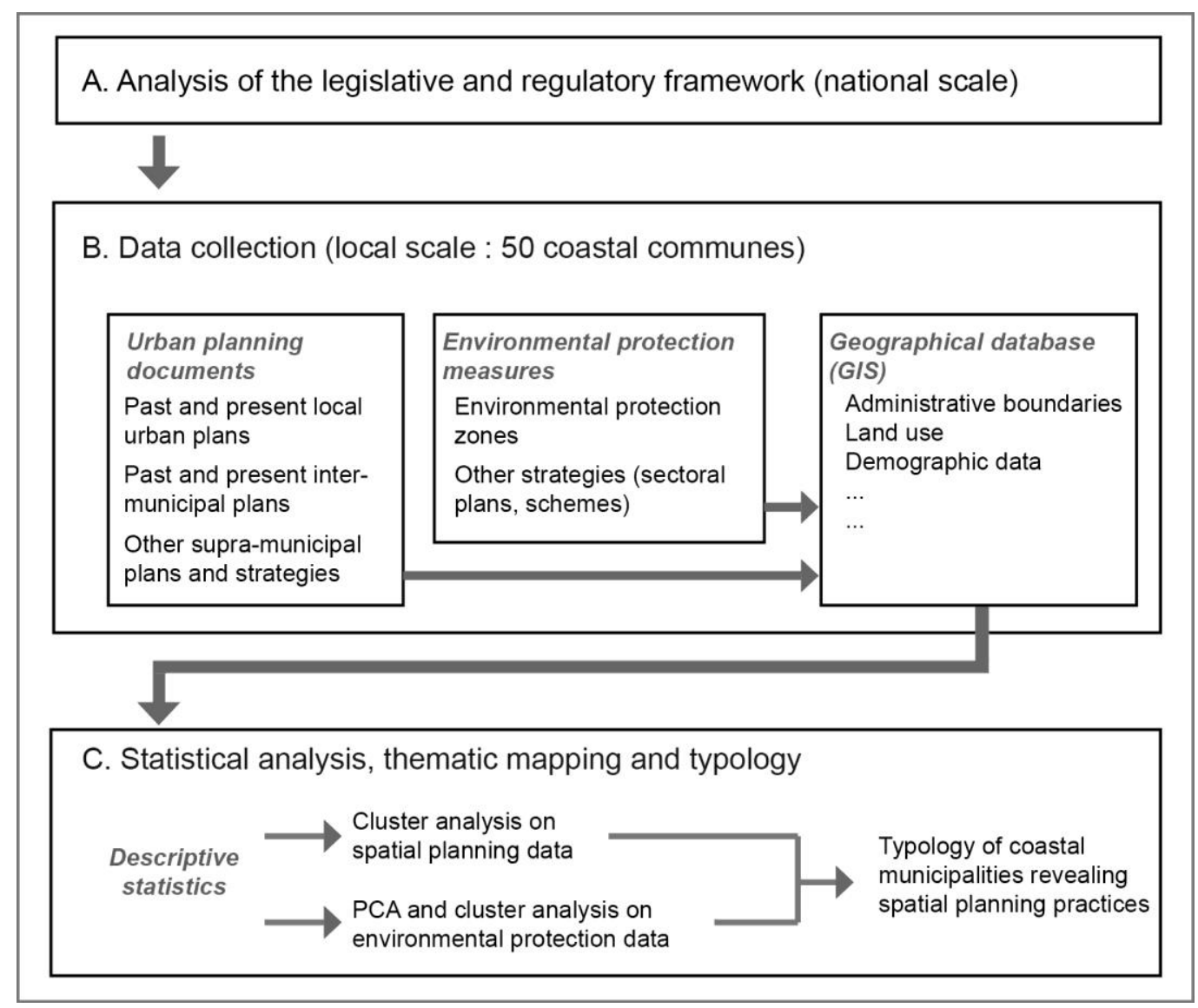

Fig. 2. Methodological framework

\subsection{Data collection}

As stated above, the study was based on extensive data collection after a thorough inventory of the laws dealing with coastal area protection and the limitation of urban sprawl. Because evolving legislation constantly introduces new tools for territorial management, it was necessary to identify the different measures used to manage and protect the environment. The gradual appearance of local and supramunicipal urban plans, environmental protection tools, schemes and strategic plans for environmental protection was investigated, starting from the 1960s. All these were arranged in the form of graphic timelines providing an overview of how the French urban planning system evolved over nearly 50 years (step A in Fig. 2).

The next step involved an exhaustive inventory of current and former planning documents and environmental protection measures implemented in the fifty communes, via a substantial collection of information (step B in Fig. 2). Urban planning data was collected between September 2014 and July 2015, 
from different sources. Institutional websites (government agencies, municipalities, intermediate administrative levels, state services) provided the basic information, which was supplemented from the urban plans themselves (local planning history is often described in the various plans), archives and other documents at the Urban Planning Agency of Marseille (AGAM), interviews with local authorities, and with the support of the local government departments in charge of spatial planning and coastal management issues (DDTM). For environmental data, GIS files were downloaded from the websites of various organizations dealing with natural area protection at a national level: the National Inventory of Natural Heritage (INPN), the Ministry of Ecology and Environment (through its local arm, DREAL), the National Observatory of the Sea and the Coasts (ONML) and the National Forestry Office (ONF). As the various environmental protection measures provide different degrees of protection against urbanization, they were ranked according to their level of constraint, at four levels: very strong, strong, medium and weak (Table 2). This ranking was based on the literature (Pelenc, 2014; Dauvin et al., 2004) and previous studies produced by government agencies (Crozet, 2010; CGDD, 2012a, CGDD, 2012b).

\begin{tabular}{|c|c|c|c|}
\hline $\begin{array}{l}\text { Level of } \\
\text { constraint on } \\
\text { urbanization }\end{array}$ & List of terrestrial protection measures & $\begin{array}{c}\text { Data } \\
\text { available } \\
\text { (for GIS } \\
\text { treatments) }\end{array}$ & \begin{tabular}{|c|} 
Year of \\
implementation \\
available (for \\
statistical \\
processing)
\end{tabular} \\
\hline \multirow{9}{*}{ Very strong } & Classified site (Site classé) & $x$ & $\mathrm{x}$ \\
\hline & Forest under forestry regime & $\mathrm{x}$ & No \\
\hline & Heart of a National Park & $\mathrm{x}$ & $\mathrm{x}$ \\
\hline & Heart of a Biosphere reserve & $\mathrm{x}$ & $\mathrm{x}$ \\
\hline & Land owned by the Coastal Conservancy & $\mathrm{x}$ & $\mathrm{x}$ \\
\hline & Natural Reserves (National, Regional and Corsican) & $\mathrm{x}$ & $\mathrm{x}$ \\
\hline & Biotope decrees & $x$ & $x$ \\
\hline & Biological reserves of the ONF & $\mathrm{x}$ & $\mathrm{x}$ \\
\hline & Sensitive natural zones owned by the Départment (ENS) & No & No \\
\hline \multirow{3}{*}{ Strong } & Regional Natural Park & $\mathrm{x}$ & $\mathrm{x}$ \\
\hline & Ramsar wetland & $\mathrm{x}$ & $\mathrm{x}$ \\
\hline & Natura 2000 sites (SPAs and SCls) & $x$ & No \\
\hline \multirow{3}{*}{ Medium } & Listed site & $x$ & \\
\hline & Member area of a National Natural Park & $\mathrm{x}$ & \\
\hline & Damping zone of a Biosphere reserve & $\mathrm{x}$ & \\
\hline \multirow{3}{*}{ Weak } & Transition zone of a Biosphere reserve & $x$ & \\
\hline & $\begin{array}{l}\text { Inventory: zone of floristic, faunal and ecological value } \\
\text { (ZNIEFF) }\end{array}$ & $\mathrm{x}$ & \\
\hline & $\begin{array}{l}\text { Inventory: zone of importance for the protection of birds } \\
\text { (ZICO) }\end{array}$ & $x$ & \\
\hline
\end{tabular}

Table 2 Classification of the environmental protection measures on the sites by level of constraint

\subsection{Classifications and typologies}


After a critical analysis of the information collected, the data most relevant to characterize the communes in terms of spatial planning trajectories over time were selected (Tables 3 and 4). These datasets were used to perform multivariate statistical analysis and cluster analysis (step C in Fig.2).

\section{Classification based on spatial planning data}

The data selected for the classification based on urban planning refer both to the planning documents in force today and to those implemented throughout the past forty years, at two levels: municipal and inter-municipal. The table used as input contains the following data for each municipality: municipal planning document currently in force; existence of a local planning document before 1983; existence of an inter-municipal plan in force today; existence of an inter-municipal plan in the past (Table 3). Documents or strategies other than local planning documents (i.e. Operation of National Interest, Territorial Planning Directive, Country Charter, Regional Development Schemes for Sustainable Development of the Territory, etc.) were identified and used to gain insights into the planning trajectories of the fifty communes; however, they were not included in the classification. The planning tools selected here are, in fact, strongly linked with local decisions and illustrate how territories evolve through urban and territorial planning. They are discussed later in the article. The data collected to perform the classification being qualitative (existence and date of implementation of a planning document), the variables were "binarized" to facilitate data processing. The result is a table with data values of "1" or "0" respectively representing either presence or absence (Table 3). Due to a lack of data for two municipalities, clustering was conducted for 48 communes. Given the relatively small size of the dataset and the fairly standard form of statistical processing required, XL Stat (Addinsoft) software was used for the analysis. Various attempts (exploratory approach) were made to identify relevant classes. Hierarchical cluster analysis (HCA) proved to be the most appropriate, using the Ward method and the Khi² distance.

\begin{tabular}{|l|c|}
\hline \multicolumn{1}{|c|}{ Variables } & Modality (Binary modality: 1 or 0) \\
\hline Municipal document in force today & PLU - 1 or 0 \\
& POS - 1 or 0 \\
& No document in force - 1 or 0 \\
\hline Existence of a local planning document before & 0 \\
1983 (POS, Communal map, MARNU) & 1 \\
\hline Inter-municipal plan in force today (SCOT) & 0 \\
& 1 \\
\hline Existence of a past inter-municipal plan (SDAU or & 0 \\
SD) for the period 1984-2000 & 1 \\
\hline
\end{tabular}

Table 3 Variables for the classification based on local and inter-municipal planning 


\section{Classification based on environmental protection data}

The classification based on environmental protection measures relies on variables indicating the power of these provisions to combat urban sprawl at municipal level and the date of their implementation (Table 4). Their strength is assessed by the proportion of the territory (percentage of the total area) covered by protection measures imposing four levels of constraint (see Table 2). Protection measures which do not impose a significant constraint on building rights were excluded from the input data set. As Table 2 shows, other datasets were not available for inclusion in the classification, which to some extent limits the analysis. However, this is mitigated by the fact that environmental protection measures very often overlap, especially those most constraining (Dauvin et al., 2004). As a result, the spreadsheet used for the classification contains four quantitative variables (Table 4). While the means of processing this dataset differed from those employed for the dataset on spatial planning, it too was analyzed using an exploratory approach. Accordingly, principal component analysis (PCA) was applied prior to hierarchical cluster analysis (HCA), using the Ward method and the Euclidian distance to reveal similarities and proximities among municipalities.

\begin{tabular}{|l|l|}
\hline \multicolumn{1}{|c|}{ Variables } & \multicolumn{1}{c|}{ Unit } \\
\hline $\begin{array}{l}\text { Proportion of the commune covered by very strong } \\
\text { protection measures (except for ENS of the Départements) }\end{array}$ & $\begin{array}{l}\text { Percentage of the surface of the } \\
\text { municipality }\end{array}$ \\
\hline $\begin{array}{l}\text { Proportion of the commune covered by strong protection } \\
\text { measures }\end{array}$ & $\begin{array}{l}\text { Percentage of the surface of the } \\
\text { municipality }\end{array}$ \\
\hline $\begin{array}{l}\text { Proportion of the commune covered by medium protection } \\
\text { measures }\end{array}$ & $\begin{array}{l}\text { Percentage of the surface of the } \\
\text { municipality }\end{array}$ \\
\hline $\begin{array}{l}\text { Age of the first very strong protection (except for ENS and } \\
\text { forest under Forestry Regime) or strong protection (except } \\
\text { for Natura 2000 sites) implemented in the commune }\end{array}$ & Number of years \\
\hline
\end{tabular}

Table 4 Variables for the classification based on environmental data

\section{Typology of territories}

The final step was to attempt to highlight different spatial planning practices combining urban and territorial planning with the use of environmental protection measures for the forty-eight communes (end of step C in Fig.2). This was not done through statistical methods, but merely by pooling the results of the two previous cluster analyses. We designed a matrix combining the two classifications, recoded into three classes for environmental protection measures and three classes for urban planning. Each cell of 
the matrix provided the number of municipalities corresponding to one of nine possible situations between two extremes: weak natural protection measures together with poor urban planning implementation, or at the opposite end of the scale, strong longstanding natural protection measures together with early and well-established urban planning.

\section{Results and discussion}

Three main groups of results are presented and discussed: first, the rather limited efficiency of the French spatial planning framework as regards coastal areas; second, spatial planning practices in these French Mediterranean coastal communes; third, the different types of spatial management in this coastal zone and their possible impact on urban sprawl.

\subsection{Limited effect of the French spatial planning framework on coastal zones}

As hypothesized from the outset, our primary finding concerns the relative ineffectiveness of the French planning framework with regard to achieving national policy objectives, i.e. limiting urban sprawl and maintaining open areas in coastal zones. This is mainly because it does not provide tools specifically directed at coastal territories, added to which there is the growing influence of local authorities in the design of local planning strategies.

The Coastal Act notwithstanding, coastal towns are not subject to a spatial planning system that differs significantly from that of the rest of the country. Our analysis of the past and present plans and environmental protection measures shows a lack of special provisions in the spatial planning tools applied to the coast. At the municipal level, planning documents have evolved over the years (Table 5), but local communes were not provided with a specific local plan by legislators. Although the principles of the Coastal Act must be integrated into the regulatory zoning of local plans, the fact that these documents can be revised means that there is no guarantee of a durable effect. Therefore, provisions which may be aimed at maintaining open areas where urbanization is banned may be eroded over time, and eventually disappear. Local authorities became more influential after the 1983 decentralization law, so this scenario might have been intensified by urban pressure and reduced government subsidies. Local decisions also have a strong impact at the supra-municipal level, and particularly at the inter-municipal level. This level is characterized by urban planning documents (Birkholz and Gille, 2006; Desjardins, 
2007), which are again common to both coastal and non-coastal territories and whose design and objectives are more or less left to the local authorities (Table 5).

\begin{tabular}{|c|c|c|c|}
\hline \multicolumn{4}{|c|}{ Municipal level } \\
\hline $\begin{array}{l}\text { Name of the } \\
\text { plan }\end{array}$ & Characteristics & $\begin{array}{l}\text { Possible period } \\
\text { of elaboration }\end{array}$ & $\begin{array}{l}\text { Possibility of the document to be } \\
\text { in force in } 2015\end{array}$ \\
\hline $\begin{array}{l}\text { Communal } \\
\text { map }\end{array}$ & simple plan, with zoning & $\begin{array}{l}\text { Before } 1983 \text { and } \\
\text { after } 2000\end{array}$ & Yes \\
\hline MARNU & $\begin{array}{l}\text { variant of the communal map, } \\
\text { with zoning }\end{array}$ & $\begin{array}{l}\text { Could be drawn } \\
\text { up between the } \\
1980 \text { s and } 2000\end{array}$ & No \\
\hline POS & $\begin{array}{l}\text { land use plan with urban regu- } \\
\text { lations and zoning. At the initia- } \\
\text { tive of the State before } 1983 \text {, of } \\
\text { local authorities after } 1983 \text {. }\end{array}$ & $\begin{array}{l}\text { From } 1967 \text { to } \\
2000 \text { (Solidarity } \\
\text { and Urban Re- } \\
\text { newal Act) }\end{array}$ & $\begin{array}{c}\text { Yes (but will soon be fully replaced } \\
\text { by the latest document) }\end{array}$ \\
\hline PLU & $\begin{array}{l}\text { local plan, replacing the POS, } \\
\text { with zoning, regulations and } \\
\text { " sustainable development ori- } \\
\text { entations », must comply with } \\
\text { SCOT }\end{array}$ & $\begin{array}{l}\text { Since } 2000 \text { (grad- } \\
\text { ually replaced by } \\
\text { inter-municipal } \\
\text { PLU since 2010) }\end{array}$ & Yes \\
\hline \multicolumn{4}{|c|}{ Inter-municipal level } \\
\hline SDAU & $\begin{array}{l}\text { Urban Planning and Develop- } \\
\text { ment Scheme (created at the } \\
\text { initiative of the State) }\end{array}$ & $1967-1983$ & No \\
\hline SD & $\begin{array}{l}\text { Master Plan (SD), which re- } \\
\text { placed the SDAU after } 1983\end{array}$ & $1983-2000$ & $\begin{array}{l}\text { No (had to be fully replaced by the } \\
\text { latest document in the } 2010 \text { s) }\end{array}$ \\
\hline SCOT & $\begin{array}{l}\text { The most modern inter-munici- } \\
\text { pal planning document. Project } \\
\text { with « sustainable develop- } \\
\text { ment orientations» }\end{array}$ & Since 2000 & Yes \\
\hline
\end{tabular}

Table 5 Local municipal planning documents: many co-existing tools

To summarize, the evolution of the French local planning framework over the past decades is key to understanding planning in the coastal zone. Today, situations vary due to the different kinds of planning documents that co-exist (Table 5). Some municipalities, for instance, have a long history of local urban plans, initiated by the State before the Decentralization Law of 1983 (Goze, 1999). In others, the first plans appeared after 1983 at the initiative of the local government, when so empowered (Priet, 2992; Newman and Thornley, 1996). Today, both groups of municipalities may be complying with the most recent French planning provisions (PLU), or they may still be operating under an older set of provisions (POS). Since the will and the capacity to plan the territory differ among municipalities, they may thus be applying different tools, whose efficacy in promoting an integrated vision of the future and in controlling urban sprawl will therefore differ too. Moreover, some municipalities still have no urban plan of their own. They fall under the national urban planning regulations (RNU), which define the basic rules for any new 
building and new developments. Urbanization is thus regulated very unevenly throughout coastal territories, and this is partly reinforced by the way environmental protection policies are implemented.

Because they emanate from various bodies or political institutions that are mainly non-local (European Union, State, Region, Province), environmental protection measures should be a set of tools that ensures a more unified and balanced policy in the coastal zone. However, local authorities can also have their say. They may oppose new projects for protected areas or, conversely, argue for and drive the protection of their natural heritage. Since natural areas with more "ordinary" biodiversity or without outstanding landscape assets may not be considered priority areas for environmental protection by the relevant institutions, there is once again scope for unequal situations. Land purchases by the Coastal Conservancy (Conservatoire du littoral), a government agency set up in 1975 with a remit to acquire non-urbanized land in coastal municipalities in order to maintain it in its natural state, open it to the general public and prevent urban sprawl, are illustrative of the various situations that local authorities may be involved in. Municipalities are indeed very often key players in the achievement of the Coastal Conservancy's objectives.

\subsection{Spatial planning practices in the French Mediterranean}

While the French legislative and regulatory framework provides territorial planning tools that apply to any municipality, the enforcement of these tools depends locally on various contextual factors such as local authorities' commitment, territorial characteristics, or urban and territorial projects. It is therefore informative to look at how local municipalities decided to provide themselves with these tools, and when. Three key dates stand out in the recent history of urban planning: 1967, when the Land Planning Law (LOF) created POS and SDAU; 1983, when urban planning was decentralized, handing over planning decisions to local officials; 2000, with the Solidarity and Urban Renewal Act (SRU) that marked planning practices by introducing PLU and SCOT to replace the former POS and SDAU.

\section{Heterogeneity of local planning practices}

In 2015, nearly all the communes studied had a PLU, approved or under development, and many of them had another local planning document prior to 2000. This widespread use of the PLU is consistent 
with what is observed at national level in coastal municipalities (SOeS et al., 2014). However, closer analysis reveals significant differences in local planning practices when starting dates and document types are considered. Explanations for this heterogeneity can be sought through a relatively straightforward analysis, taking into account the present and past planning context, demographic trends and political motivations.

For instance, in 2012, ten municipalities out of forty-eight had less than 2,000 inhabitants (population census data, INSEE, 2012) and therefore did not come into the "city status" category as defined by INSEE. Of these ten communes, four still had no local urban plan. In contrast, of the six municipalities with more than 30,000 inhabitants, five had a PLU. Moreover, the 1982-2012 period reveals interesting demographic trends. First, all the cities with no local urban plan today show the lowest population growth rate (from $-17 \%$ to $+54 \%$ ), below the median value. Second, $75 \%$ of the municipalities belonging to the upper quartile as regards population growth (between $+98 \%$ and $+322 \%$ ) had a local planning document before 1983. There seems to be a link, therefore, between current lack of a planning document and a history of low population and moderate demographic growth. This is consistent with the findings of another study at national level, showing the relationship between the size of the territory and the use of MARNU instead of POS after 1983 (Priet, 1992). Moreover, there seems to be another link between strong demographic trends and precocity of local planning, even though until 1983, at the request of the State, some territories were also urged to develop a POS (Goze, 1999).To summarize, as far as demography is concerned, it appears that implementation of local planning tools depends on the number of inhabitants and the population dynamics.

To get a clearer picture of the heterogeneity observed in local planning, it is instructive to compare two territories: the Marseille coastal zone and the coast of Balagne, in Corsica (Fig. 3). As regards spatial planning at a municipal level, the Marseille coastal zone appears to be one step ahead. Before 1983, $75 \%$ of the towns already had a POS. In contrast, on the coast of Balagne before 1983 , local planning was almost nonexistent: only two towns had a communal map. Between 1983 and 2000, the number of planning documents increased: either POS (5 towns) or the communal map or its MARNU variant (4 towns). Today, urban planning provision in Balagne is still very heterogeneous: there are 5 PLU (approved) and 2 POS, and 5 municipalities (out of 12) have no plan, so that they fall under the restrictive national planning regulation (RNU). However, standardization seems to be the main trend. Almost all the communes where the RNU is in force have started the procedure to obtain their own PLU. The 
region's attractiveness and the obvious anthropogenic pressures (CGDD, 2012a) may explain the implementation of urban planning policies. The fact that land is being opened up to urbanization through some current PLU zoning partially reflects these dynamics (Tafani, 2010).
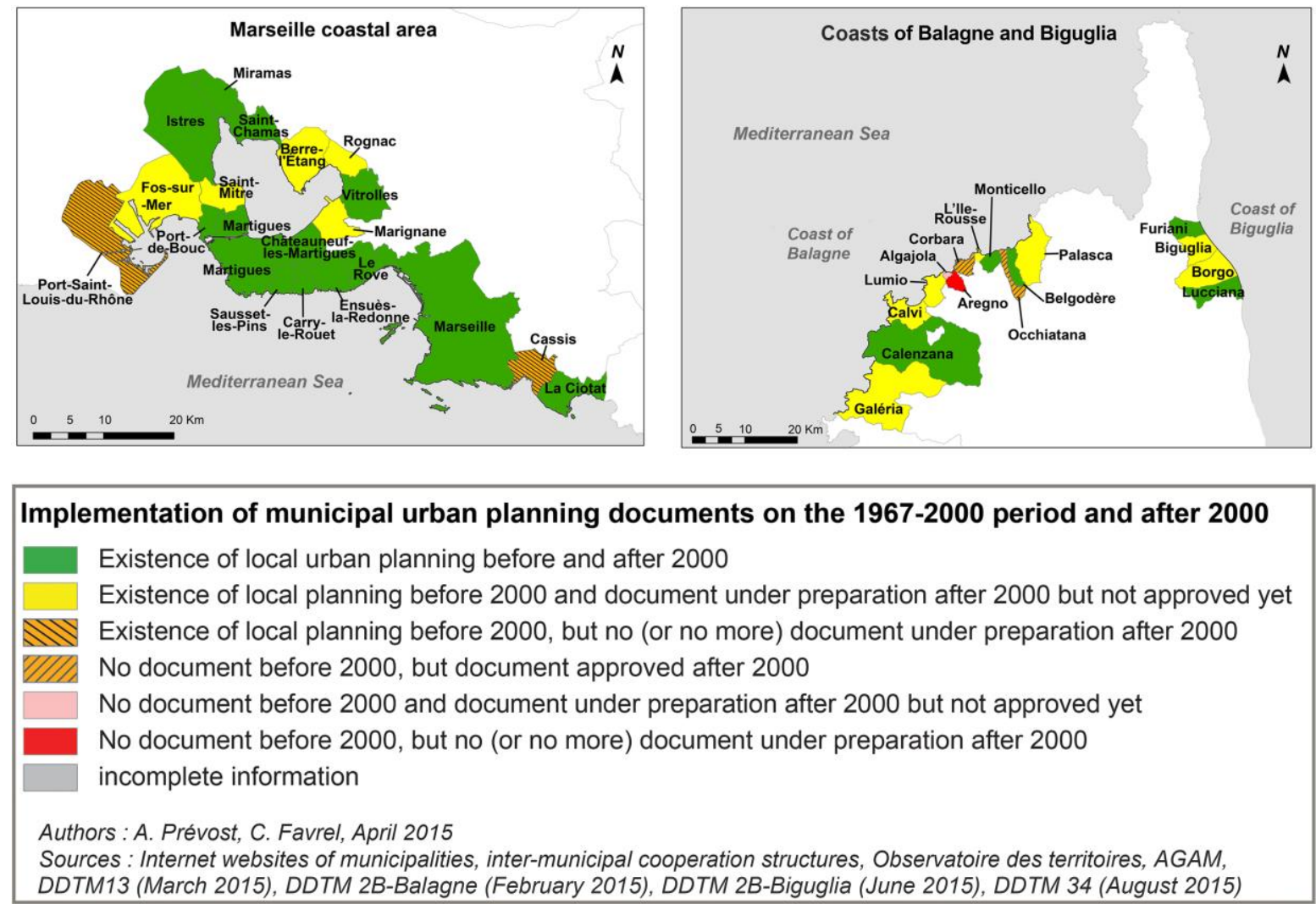

Fig. 3. Implementation of local urban planning, on the coast of Marseille and the Corsican sites

The contrast between Marseille and Balagne may be explained by certain driving factors related to the geographical, political and economic context. The early land planning in the Marseille coastal area is partially the result of national initiatives. The government's will to develop the industrial port function around the Berre lagoon and the Gulf of Fos (Borruey, 2006), and the State's intention to plan the overall development of the site (indicated in the OREAM scheme - Organization for Studies to Develop and Plan the Marseille Metropolitan Area - in 1969), can be seen as incentives for the emergence of local initiatives. In Balagne, the story is different. The recent territorial development really started in the 1980s, so that there was no specific need to start land planning earlier. Moreover, the economic development of Corsica as a whole was a major concern, and urbanization arising from increased tourism and real estate development might have been considered a solution. Nevertheless, Balagne's local urban planning history seems to be idiosyncratic, although this particular situation is common throughout Northern 
Corsica ${ }^{2}$. This raises a number of questions. Given that coastal overdevelopment got off to a strong start in the 1980s, the relatively extensive use of simple planning documents appears inappropriate. The fast growing urbanization taking place at that time should have warranted the use of more elaborate planning documents by local authorities. Yet a significant number of simple planning documents were issued. Were they used for their simplicity and their relevance to local issues? Or were more complex urban planning documents avoided, in order to bypass the "rule of limited constructability" and thus to allow urban development? This question would seem to deserve further examination.

\section{Late implementation of inter-municipal planning}

At the supra-municipal level, the history of spatial planning reveals a paradox, which concerns the Marseille coastal zone and the Gulf of Aigues-Mortes. By the 1960s, both areas were being targeted by strong State initiatives which could have shown the way forward in terms of inter-municipal cooperation. In the Marseille area, there was the approval of the OREAM scheme in 1969 (Douay, 2009), and the developments around the Berre lagoon. In the Gulf of Aigues-Mortes, the will to develop tourism led to the "Racine Plan" (1963), a regional master plan to develop tourism infrastructures in the LanguedocRoussillon region, which resulted in the ex-nihilo creation of seaside resorts such as La Grande Motte and Port-Camargue (Cazes, 1972). Surprisingly, however, these key initiatives did not encourage intermunicipal planning practices. Before 2000 , both areas were characterized by a lack of master plan, and only four towns near Marseille were covered by an SDAU approved in 1979. While some attempts at inter-communal planning were made in the past, such as for the Marseille urban area and for the Montpellier urban area, these procedures were never completed (Volle, 1985; AGAM, 2013). To some extent, this is representative of what happened at national level (Althapé, 2000; Desjardins, 2007), but it is particularly true of the Mediterranean. In 1992, out of a total of about 200 SD approved in France, only four were located along the Mediterranean coast. Today, however, the difficulty inherent in creating inter-communal policies in the Mediterranean is being overcome. Aside from the coast of Biguglia, all the communes now have an inter-communal plan in development or approved, which is in line with the

2 The website of the State services in Northern Corsica states "the Département of Haute-Corse overall has few town plans". Source : http://www.haute-corse.gouv.fr/etat-d-avancement-des-documents-durbanisme-en-a195.html, consulted on September 10, 2015 
situation nationwide (DGALN, 2007). Moreover, inter-municipal cooperation initiatives to define strategies and policies over a wider territory in the Mediterranean indicate willingness to change and improve planning practices, by enhancing cooperation between adjacent territories ${ }^{3}$. In this context, Corsica is unique: the island has been part of a regional planning approach under a comprehensive development plan since 1992, soon to be replaced by the regional PADDUC (Tafani, 2010), with no equivalent in the rest of France.

To summarize, in addition to the heterogeneity observed in local planning, spatial planning practices in the communes studied clearly got off to a late start.

\section{Uneven use of environmental protection measures}

Our results on the use of protection measures for natural areas divide the municipalities into three groups. Twelve towns have a high proportion of their area covered by longstanding strong and/or very strong protection measures. Two municipalities are fully covered by less restrictive protection tools. Thirty-six towns have smaller proportions of their territory protected, whatever the level of protection. In order to pinpoint the territories with the lowest level of protection, this latter class was split into two subcategories (Fig. 4). Correlation analysis performed to detect any size-effect between the proportion of the territory protected and the profile of the municipality (area, population, past demographic trends) indicates that the protection of natural areas in a given commune cannot be related to its size or its recent demographic dynamics.

${ }^{3}$ Inter-Scot procedures on the Marseille coastline and the Aigues-Mortes gulf site: Inter-Scot DECAMED; Inter-Scot Rhône-Durance-Vaucluse; Inter-Scot des Bouches-du-Rhône (source http://www.pays-arles.org/informations-pratiques/le-scot/article/interscot, consulted on February 1, 2015); Inter-Scot du Languedoc-Roussillon (IAU-IDF, 2010). 

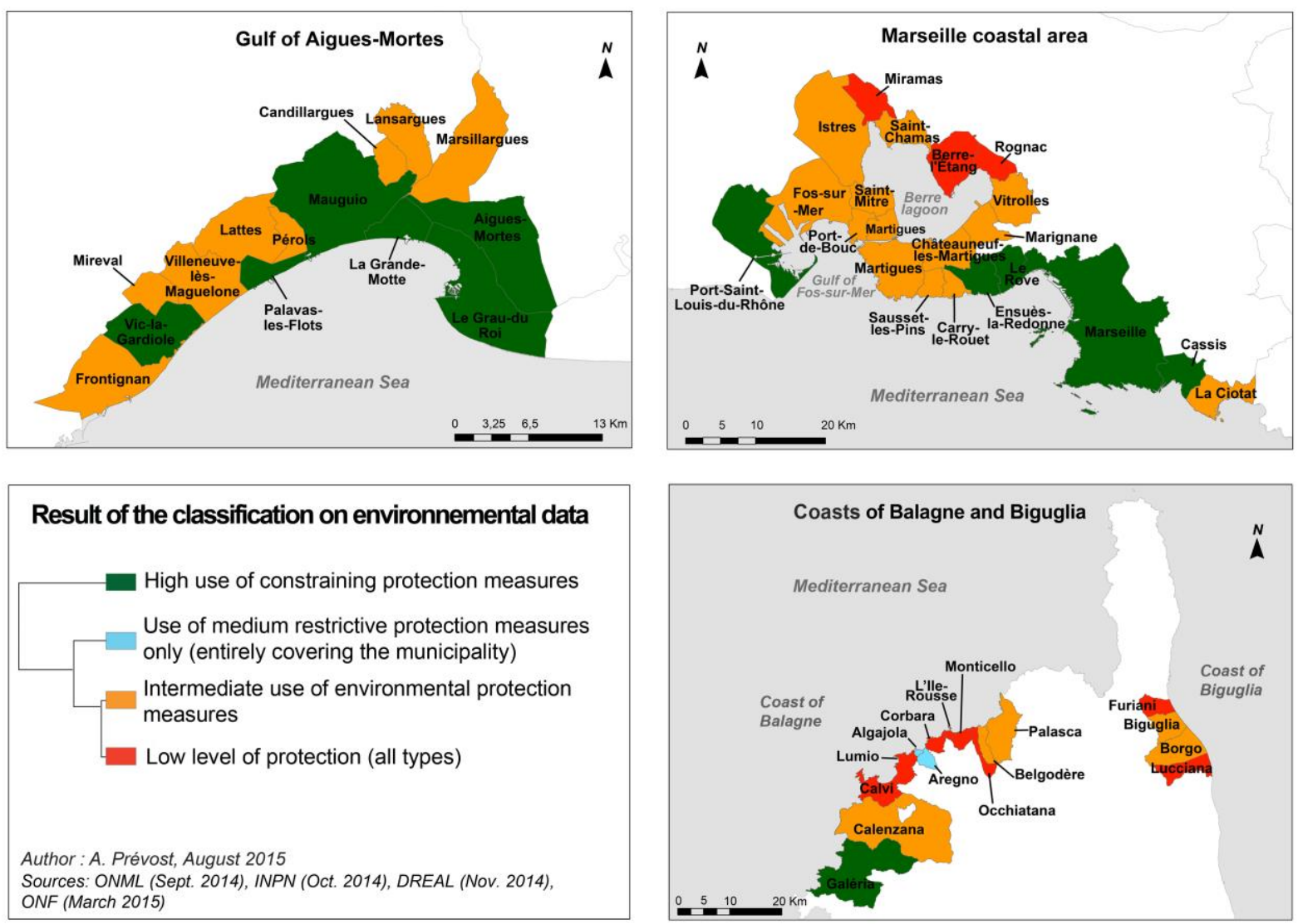

Fig. 4. Use of environmental protection measures on the sites studied

One of the factors explaining such differences in environmental protection is the intrinsic ecological and landscape assets of the territory of a given commune, as well as the role it plays in the economic development of the zone where it is located. Major sites of interest like the Marseille creeks and the lagoons of the Gulf of Aigues-Mortes seem to have received special attention (Fig. 4). While protection measures emanate from various bodies, local initiatives covering more ordinary landscape may result in the protection of large areas. For instance, two communes close to Marseille (Le Rove and Ensuès la Redonne) benefited greatly from local officials' determination to limit urbanization, which led to strong and lasting protection. The municipalities where protection is less widespread (an intermediate level) appear to fall into two categories (Fig. 4). They may be located in coastal areas whose ecological or landscape assets are not outstanding, like the area inland of the Gulf of Aigues-Mortes. Or they may be involved in major development projects incompatible with strong protection of the environment. For instance, the communes surrounding the Berre lagoon and the Gulf of Fos-sur-Mer, near Marseille, have undergone industrial-port development since the 1960s. The coast of Biguglia, which is the only space left for the city of Bastia's urban and economic expansion, is in a similar situation, with intermediate or low levels of 
protection of its natural areas. While the towns situated around the lagoon of Biguglia have high levels of protection, this covers only a small part of their territory, the protection measures being generally limited to the area close to the lagoon shoreline. Today, the dynamics of this coastal zone give cause for concern in terms of urban sprawl: there was a sharp increase in artificial areas over the period 20022011 (Robert et al., 2015). The coast of Balagne, too, reflects a variety of situations that echo the observations made above. While exceptional territories in terms of biodiversity and landscape are well protected in the South (they are part of the regional park of Corsica), more "ordinary" territories, small and relatively highly urbanized, are poorly protected in the central part of the coastal zone.

This second set of findings shows that, locally, there is significant diversity in the spatial planning practices connected with urban planning and in the environmental protection measures implemented. In the four coastal zones, the planning tools in force today differ, and the use of measures to protect the environment is rather disparate.

\subsection{Different types of spatial management}

To better define the various situations observed in the 48 municipalities, we combine their urban planning trajectories with their use of environmental protection measures. In addition, a more detailed description of selected communes is given, to illustrate the principal situations.

\subsubsection{Nine possible types of spatial management}

As shown in Table 6, the French Mediterranean coastal zone appears to be characterized by highly diverse practices regarding spatial planning tools and the implementation of provisions to protect natural areas. When the number of municipalities for each type of urban planning trajectory (from the most basic (A) to the most modern $(\mathrm{C})$ at the municipal level) and each level of environmental protection (from the lowest (3) to the highest (1)) is considered, the distribution of the municipalities in the matrix shows that there is no straightforward relationship between an elaborate level of planning and a high level of environmental protection. Municipalities may be characterized by a very poor urban planning history yet have a very high or intermediate level of use of constraining protection measures; others may have a long and elaborate planning history but no environmental protection at all. 
Urban planning trajectory

\begin{tabular}{|c|c|c|c|c|}
\hline & A. Poor & B. Intermediate & C. Elaborate & Total \\
\hline 1- High & 1 & 5 & 4 & 10 \\
\hline 2- Intermediate & 2 & 10 & 15 & 27 \\
\hline コ. & 2 & 3 & 6 & 11 \\
\hline Total & 5 & 18 & 25 & 48 \\
\hline
\end{tabular}

\footnotetext{
Urban planning trajectory

A : Municipalities without a local plan, no former or current inter-municipal plan in force former inter-municipal plan towns (4) previously under SD

Level of environmental protection in use:

1 : High level of constraining protection measures, fairly longstanding

2 : Intermediate level of environmental protection

3 : Low level of protection measures (all types)
} B : Municipalities with POS, $61 \%$ of them with a planning document before $1983,61 \%$ under SCOT, no

C : Municipalities with PLU, 64\% with a planning document before 1983, about $50 \%$ under SCOT. A few

Table 6 Combined matrix: classification of municipalities on planning and environmental data

Beyond this very first observation, it is instructive to look more closely at the $\mathrm{C} 2$ category, the most frequent type, with 15 municipalities. It is composed of towns ranked as "intermediate" on environmental protection, but which have quite an elaborate planning history. They have a current PLU and eleven of them already had a municipal planning document before 1983. To some extent, we can assume that these towns had a double objective: they opted for allowing economic development without overly compromising natural areas. For instance, six of them (situated around the lagoon of Berre and the Gulf of Fos) are characterized by industrial and logistics activities and two others (on the Blue Coast, near Marseille) are engaged in tourism and real estate development. The B2 category is the second largest (10 municipalities). Its towns have a similar intermediate level of environmental protection of the environment, but their local urban planning documents are not in keeping with the most recent legislation They appear to have had difficulty achieving their local planning objectives over recent years. The reasons for this probably vary, from the usual difficulties inherent to procedure itself, to an intentional passiveness that may suit local interests. 
The municipalities where local planning is the most elaborate (column C) show various levels of environmental protection, but the $\mathrm{C} 1$ and $\mathrm{C} 3$ categories are worthy of note. $\mathrm{C} 1$ includes only four towns having a current PLU and which are also very well protected environmentally. Three are municipalities located in the Marseille coastal zone (Marseille, Ensuès - La Redonne, Le Rove) and one is in the gulf of Aigues-Mortes (Mauguio). All these towns were involved in planning early, and come under an intermunicipal development plan. Therefore, they can be considered as the type most proactive in controlling urban sprawl on the coast; however, it would take more detailed analysis of the local planning documents themselves and of land use evolution in recent years to confirm this hypothesis. In contrast, the C3 group is composed of six towns also having PLU but where the level of environmental protection is the lowest. Most of them are in Corsica (5). Even though they have a PLU today, they started their planning process quite late: only one of them initiated urban planning before 1983 and two did not have any planning document before approving a PLU. Moreover, five of these towns are not covered by an inter-municipal plan. This group is therefore very different from the previous one, with an apparently weaker commitment to combat urban sprawl.

The main conclusion that can be drawn from Table 5 is that the urbanization of the French Mediterranean coastal zone is not managed effectively by local spatial planning practices. Of the municipalities studied, only four show signs of a real attempt to prevent urban sprawl. Moreover, while a third of the municipalities show a reasonable degree of commitment to urban planning, they show only a moderate commitment to the protection of natural areas (C2 category). This suggests that although these towns may be interested in combatting urban sprawl, they are even more interested in planning their future development. Added to this group are other towns in the B2 category, where spatial planning is weaker: either more flexible with new urbanization projects, or less proactive in creating more sustainable territories. These patterns can be observed in many other territories not located in coastal areas. They are clearly related to the complexity of defining priorities among urban development, environmental protection, and control of urban pressure, and undoubtedly explain why urban sprawl persists along the coasts.

\subsubsection{Four local trajectories}


Wider analysis of four communes yields a more detailed picture of the situations observable within the 48 communes studied. These towns belong to four different categories illustrated on the lower left corner / upper right corner axis in Table 6. Each belongs to a different study area (Table 7).

\begin{tabular}{|c|c|c|c|c|c|}
\hline & $\begin{array}{c}\text { Spatial } \\
\text { management } \\
\text { category }\end{array}$ & C1 & C2 & B2 & A3 \\
\hline & $\begin{array}{l}\text { Name of } \\
\text { commune }\end{array}$ & Le Rove & $\begin{array}{l}\text { Villeneuve-lès- } \\
\text { Maguelonne }\end{array}$ & Borgo & Lumio \\
\hline & Coastal zone & Marseille & $\begin{array}{c}\text { Gulf of Aigues- } \\
\text { Mortes }\end{array}$ & Biguglia & Balagne \\
\hline & Area * & 23.1 & 31.3 & 48.3 & 19.5 \\
\hline \multirow{3}{*}{ Population \# } & 1968 & 1709 & 1797 & 1600 & 473 \\
\hline & 1982 & 2707 & 3003 & 3413 & 747 \\
\hline & 2012 & 4507 & 9436 & 7950 & 1212 \\
\hline \multirow{2}{*}{$\begin{array}{l}\text { Local } \\
\text { planning } \\
\text { documents }\end{array}$} & Local documents & $\begin{array}{l}\text { POS (1982), } \\
\text { PLU (2009) }\end{array}$ & $\begin{array}{l}\text { POS (1983), } \\
\text { PLU (2013) }\end{array}$ & $\begin{array}{c}\text { POS } \\
(1987)\end{array}$ & $\begin{array}{l}\text { Communal Map } \\
\text { (1985), RNU today }\end{array}$ \\
\hline & $\begin{array}{l}\text { Inter-municipal } \\
\text { documents }\end{array}$ & $\begin{array}{l}\text { SDAU (1979), } \\
\text { SCOT (2012) }\end{array}$ & SCOT (2006) & No & $\begin{array}{l}\text { SCOT (under } \\
\text { development) }\end{array}$ \\
\hline \multirow{4}{*}{$\begin{array}{l}\text { Environmental } \\
\text { protection ** }\end{array}$} & Very strong & 88.9 & 24.7 & 29.3 & 3.3 \\
\hline & Strong & 86.4 & 63.4 & 27.8 & 0 \\
\hline & Medium & 0 & 0.3 & 0 & 1.5 \\
\hline & Weak & 88.2 & 64.5 & 31.9 & 12.2 \\
\hline
\end{tabular}

Population census data, INSEE $2012 ;{ }^{*}$ in square $\mathrm{km} ;{ }^{* *}$ in $\%$ of the municipal area

Table 7 Major characteristics of Le Rove, Villeneuve-lès-Maguelonne, Borgo and Lumio in terms of spatial planning

Belonging to the $\mathrm{C} 1$ category, Le Rove is an emblematic municipality: local authorities decided very early to maintain its rural and natural character and to limit urbanization. In the seventies, they fought successfully against a huge real estate project connected with a marina, which was designed with a capacity of more than 55,000 beds. Located on the outskirts of Marseille, this commune then committed itself to a very protective strategy for its territory. It took advantage of the State's desire to promote spatial planning on the stretch of coast between Marseille and Martigues, known as the Blue Coast (Côte bleue). This meant that the commune was regularly provided with the latest land planning documents. Simultaneously, it managed to protect its territory with strong environmental protection measures. At the beginning of the 1980s, it had a large proportion of its total area purchased by the Coastal Conservancy (nearly $20 \mathrm{sq} \mathrm{km}$ ), the largest land acquisition by this agency until recently (13 sq km were also purchased in a nearby town, Ensuès La Redonne). In the 2000s, another initiative led a very large part of the same area being declared a "classified site" (site classé) under the 1930 Law about the "protection of natural monuments and sites of an artistic, historical, scientific, legendary or picturesque character". In the same period, the Calanques National Park (created in the southern part 
of the Marseille coastal zone in 2012) was under study. The possibility that part of the Blue Coast might be included was explored, but the idea was abandoned because of a lack of consensus among stakeholders. However, despite fairly strong population growth in recent decades $(+66 \%$ between 1982 and 2012), Le Rove is clearly a commune where urban sprawl has been kept under control (Robert, 2016).

Located a few kilometers from Montpellier, Villeneuve-lès-Maguelonne in the gulf of Aigues-Mortes belongs to the $\mathrm{C} 2$ category. Like Le Rove, this commune provided itself with the relevant local planning documents whenever they were created by law, but it did not come under an inter-municipal master plan before 1983 , undoubtedly due to a lack of interest by the State. Lying both on the seashore and in the lagoon complex of Palavas-les-Flots, Villeneuve-lès-Maguelonne is an old settlement that hosted the episcopal headquarters of its region in the Middle Ages. It is a unique place, with strong reminders of the past (the ruins of the medieval cathedral still remain on the island where the town stood at that time) and outstanding natural landscape and biodiversity. Conserving the lagoon and old salt marshes was the incentive behind the protection of large expanses of the area (Coastal conservancy, wetlands under the Ramsar Convention, Natura 2000), but overall Villeneuve-lès-Maguelonne has been less protective than Le Rove. Moreover, a smaller proportion of the land is protected, probably because a major part of the municipal area has long been dedicated to agriculture, which is now suffering the effects of urban expansion (Abrantes et al., 2010). Today, the northern part of the commune, which is inland and near the city of Montpellier (approximately 270,000 inhabitants), is the main urbanized area. It therefore falls under the very strong urban dynamics fostered by Montpellier, the capital of the province, explaining the strong demographic increase of recent years (+214\% between 1982 and 2012) and jeopardizing the management of urban sprawl in the area.

Borgo, in Corsica, is located on the shores of Biguglia lagoon. In our typology, it is considered as having an intermediate position (category B2). Like Villeneuve-lès-Maguelonne, it has protected areas because of the lagoon and associated wetlands. However, the areas under protection are smaller and the level of protection is lower than in Villeneuve-lès-Maguelonne. Large parts of the commune are therefore potentially open for new development, especially since spatial planning initiatives have not been very proactive until now. Although the first municipal planning document was produced in 1987, it did not cover the entire territory. Moreover, unlike the two other towns, Borgo still has no PLU, the most recent town planning document in force at that level. This is because the local representatives of the State did 
not approve the proposed plan in the early 2010s. In addition, no inter-municipal master plan of any kind was ever produced in this part of Corsica, an obvious handicap, as it is a fast-growing area. Between 1982 and 2012, the town of Borgo recorded a population increase of $+113 \%$. The territory, too, has changed quite remarkably in recent years, with a $4 \%$ mean annual growth rate for artificial areas between 2002 and 2011, due to the building of housing, the development of industrial and logistics areas, the construction of recreational and tourism facilities, as well as transport infrastructures (Robert et al., 2015).

Located in the other coastal zone that we studied in Corsica, Lumio belongs to the A3 category. Environmental protection is rather limited and urban planning is almost non-existent; both municipal and inter-municipal plans have been in development for years. It is a small village with a permanent population of around 1,200 inhabitants, which is also very attractive (and costly) as a location for second homes and summer holidays. It features a famous seaside development (marina Sant'Ambrogio) spatially disconnected from the old village, which stands in the hills dominating the sea. The territory undergoes strong pressure, both from local residents in search of housing and from real estate investors with projects for new developments. However, as the commune comes under national urban planning regulations, the municipality does not have the only say on the urbanization issue. There is constant liaising with the State representatives in Bastia, who examine every building project proposal individually, without reference to any integrated and prospective project for the territory. This situation is rather ambiguous; while the decentralization law handed over to local authorities decision-making powers for their territory, Lumio's elected representatives did not really take on this new responsibility. The result is a kind of territorial stalemate, because the State representatives are not eager to replace the municipality. Very few building projects are authorized, and of those, some are difficult to reconcile with the main legislative principles.

As shown with these four examples, spatial management of the coastal zone in the French Mediterranean is somewhat uneven. However, while the typology allows a better understanding of the general context, more local research needs to be done, based on field work and interviews with local stakeholders, to facilitate interpretation.

\section{Conclusions}


France is well known for its legislative and regulatory spatial planning framework, which provides coastal areas with specific provisions like the Coastal Act and the Coastal Conservancy. These provisions are intended to counteract the substantial pressures that these territories have been undergoing for years. Nevertheless, our study highlights the relative lack of special provision for the coastal zone itself in local spatial planning tools, showing that French coastal municipalities are subject to roughly the same statutory and regulatory framework as the rest of the country. The study of fifty Mediterranean coastal towns reveals that, while these territories are subject to the same legal framework, they follow different trajectories of local development, preservation of natural areas and resistance to urban sprawl. First, the use of environmental protection measures varies greatly from one local territory to another, probably strongly linked to past development projects and the intrinsic value of natural spaces. Second, local planning practices are still disparate, even though procedures are becoming more standardized. Third, with local authorities becoming more and more influential, there are discrepancies between spatial planning in the coastal zone and the objectives of national guidelines (national policy but local strategies).

Exploring the mechanisms that contribute to coastal planning and to the limitation of urban sprawl is a long-term undertaking, and this work could usefully be extended in at least two directions. First, it would be worth looking at a larger selection of specific "trajectories" of spatial planning, thus enriching the current analysis, at the same time examining land use / land cover evolution over time. A set of municipalities could be assessed, mapping their land use / land cover on a large scale at different dates. Using GIS and spatial analysis, the data could be analyzed to quantify urban sprawl and urban renewal, as in other similar studies (Chen et al., 2005; Catalàn et al., 2008; Bhatta et al., 2010; Su et al., 2010; Sparfel et al., 2011; Pons and Rullan, 2014; Robert, 2016; Romano and Zullo, 2014). The same data could also be compared with the regulatory zones from urban planning documents, to shed light on the rationale behind their design and to assess its relevance, as done for Lisbon in another study (Abrantes et al., 2016). Moreover, it would be useful to include other documents like strategic schemes and risk mitigation plans that can interfere with land use evolution. Attempts to predict future trends through modelling could then be made, offering scenarios based on spatial analysis and models like those developed by Petrov et al. (2009) or Poelmans and Van Rompaey (2009). Second, further investigations could take into ac- 
count socio-demographic dynamics and lean towards more qualitative information, for instance by conducting more structured interviews with local stakeholders, to refine our understanding of the doctrines determining planning principles and which have certainly shaped the territories. In the end, the analysis of public policies at local level requires a multifaceted approach, including spatial, socio-cultural and political analyses.

\section{Acknowledgments}

This work received financial support from the Human-Environment Observatory of the Mediterranean Coast (OHM littoral méditerranéen) and of the DRIIHM Labex, CNRS.

\section{Bibliography}

Abrantes, P., Fontes, I., Gomez, E., Rocha, J., 2016. Compliance of land cover changes with municipal land use planning: Evidence from the Lisbon metropolitan region (1990-2007). Land Use Policy, 51, 120-134. doi:10.1016/..landusepol.2015.10.023

Abrantes, P., Soulard, C., Jarrige, F., Laurens, L., 2010. Dynamiques urbaines et mutations des espaces agricoles en Languedoc-Roussillon (France). Cybergeo: European Journal of Geography, document 485. doi: 10.4000/cybergeo.22869

AGAM., 2013. Marseille de la ville à la métropole, un demi-siècle d'histoire urbaine. AGAM, Marseille. Catalogue de l'exposition du 24 novembre 2013 au 9 mars 2013.

Althapé, L., 2000. Simplifier et décentraliser: deux défis pour l'urbanisme. Sénat, Paris. Rapport d'information fait au nom de la commission des Affaires économiques et du Plan par le groupe de travail sur la modernisation du droit de l'urbanisme, $N^{\circ} 265$, SÉNAT, session ordinaire de 1999 2000, 101 pp. URL: http://www.senat.fr/rap/r99-265/r99-2651.pdf

Bhatta B., Saraswati S., Bandyopadhyay D., 2010. Quantifying the degree-of-freedom, degree-ofsprawl, and degree-of-goodness of urban growth from remote sensing data. Applied Geography, 30, 96-111. doi:10.1016/j.apgeog.2009.08.001

Becet, J-M., 1987. L'aménagement du littoral. PUF, Paris, Coll. Que sais-je ? N²363, 127 pp.

Benoit, G., Comeau, A. (Eds), 2005. A Sustainable Future for the Mediterranean. The Blue Plan's Environment and Development Outlook. Earthscan, London, 464 pp.

Borruey, R., 2006. Les villes nouvelles françaises ou l'intercommunalité forcée le cas des rives de l'étang de Berre. Rives nord-méditerranéennes, 25, 65-78. URL : http://rives.revues.org/596

Bouyer, C., 2004. Construire ensemble un développement équilibré du littoral. La Documentation française / DATAR, Paris, $156 \mathrm{pp}$.

Burak, S., Doğan, E., Gazioğlu, C., 2004. Impact of urbanization and tourism on coastal environment, Ocean and Coastal Management, 47, 515-527. doi:10.1016/j.ocecoaman.2004.07.007

Capineri, C., Lazzeroni, M., Spinelli, G., 1995. Mediterranean France: in search of balance. In: Gisela Cortesi (Ed.), Urban Change and the Environment: The Case of the North-Western Mediterranean. Guerini, Milano, 65-93.

Catalàn, B., Saurí, D., Serra, P., 2008. Urban sprawl in the Mediterranean?: Patterns of growth and change in the Barcelona Metropolitan Region 1993-2000. Landscape and Urban Planning, 85, 34, 174-184. doi:10.1016/j.landurbplan.2007.11.004

Cazes, G., 1972. Réflexions sur l'aménagement touristique du littoral du Languedoc-Roussillon. L'Espace géographique, 1, 193-210. doi : 10.3406/spgeo.1972.1341 
CGDD, 2011. Environnement littoral et marin - chapitre I: démographie et occupation du sol. Service de l'observation et des statistiques, RéférenceS, 16 pp. URL: http://www.statistiques.developpement-durable.gouv.fr/fileadmin/documents/Produits_editoriaux/Publications/References/2011/R\%C3\%A9f\%C3\%A9renceS\%20Littoral\%20\%20chap.\%201\%20\%28p.13\%20\%C3\%A0\%2028\%29.pdf

CGDD, 2012a. Trois quarts des rivages métropolitains sont non artificialisés mais une part importante est menacée et peu protégée. Observation et statistiques Environnement, Le Point sur, 153, 4 pp. URL: $\quad$ http://www.statistiques.developpement-durable.gouv.fr/publications/p/1939/1143/troisquarts-rivages-metropolitains-sont-non-artificialises.html

CGDD, 2012b. Typologie des communes littorales maritimes suivant l'artificialisation et les protections mises en œuvre sur leur bande côtière. Méthodes de traitements et résultats. Service de l'observation et des statistiques, $5 \mathrm{pp}$. URL: http://www.onml.fr/uploads/media/typologie.pdf

Chen, S., Chen, L., Liu, Q., Li, X., Tan, Q., 2005. Remote sensing and GIS Based integrated analysis of coastal changes and their environmental impacts in Lingding Bay, Pearl River Estuary, South China. Ocean and Coastal Management, 48, 65-83. doi:10.1016/j.ocecoaman.2004.11.004

Chuman, T., Romportl, D., 2010. Multivariate classification analysis of cultural landscapes: An example from the Czech Republic. Landscape and Urban Planning, 98, 3-4, 200-209. doi:10.1016/j.landurbplan.2010.08.003

Cocossis, H. N., 1991. Historical land use change in Europe: Mediterranean regions of Europe. The GeoJournal Library, 18, 441-461. doi: 10.1007/978-94-011-3290-9_20

Conway, T. M., Lathrop Jr, R. G., 2005. Modeling the ecological consequences of land-use policies in an urbanizing region. Environmental Management, 35 (3), 278-291. doi : 10.1007/s00267-0044067-x

Cori, B., 1999. Spatial dynamics of Mediterranean coastal regions. Journal of Coastal Conservation, 5, 105-112. doi: 10.1007/BF02802747

Cortesi, G., 1995. Urban Change and the Environment: The Case of the North-Western Mediterranean. Guerini, Milano, $347 \mathrm{pp}$.

Crawford, T.W., 2007. Where does the coast sprawl the most? Trajectories of residential development and sprawl in coastal North Carolina, 1971-2000. Landscape and Urban Planning, 83, 3, 294-307. doi:10.1016/j.landurbplan.2007.05.004

Dagorne, A., 1995. La Côte d'Azur, un mur de béton ?. Recherches Régionales Alpes-Maritimes et Contrées Limitrophes, 3, 165-216.

Daligaux, J., Minvielle, P., 2010. De la loi Littoral à la Gestion Intégrée des Zones Côtières. Méditerranée, 115, 54-67. URL : http:// mediterranee.revues.org/5122

Dauvin, J.C., Lozachmeur, O., Capet, Y., Dubrulle, J.B., Ghezali, M., Mesnard, A.H., 2004. Legal tools for preserving France's natural heritage through integrated coastal zone management. Ocean \& Coastal Management, 47, 463-477. doi:10.1016/j.ocecoaman.2004.09.004

Davis, B.C., 2004. Regional planning in the US coastal zone: a comparative analysis of 15 special area plans. Ocean \& Coastal Management, 47, 1-2, 79-94. doi:10.1016/j.ocecoaman.2004.03.005

Deboudt, P., Dauvin, J.-C., Lozachmeur, O., 2008. Recent developments in coastal zone management in France: The transition towards integrated coastal zone management (1973-2007). Ocean \& Coastal Management, 51, 3, 212-228. doi:10.1016/j.ocecoaman.2007.09.005

Desjardins, X., 2007. Gouverner la ville diffuse. La planification territoriale à l'épreuve. (Doctoral thesis). Université Panthéon-Sorbonne - Paris I. 528 pp. URL: https://tel.archives-ouvertes.fr/tel-00250015

DGALN, 2007. Bilan de la Loi Littoral et des mesures en faveur du littoral. Rapport du Gouvernement au Parlement, 127 pp. URL : http://www.datar.gouv.fr/bilan-de-la-loi-littoral-et-des-mesures-enfaveur-du-littoral-rapport-du-gouvernement-au-parlement-2

Direction Générale des Entreprises, 2014. Key facts on tourism. URL: http://www.entreprises.gouv.fr/files/files/directions_services/etudes-et-statistiques/statstourisme/chiffres-cles/CC_Tourisme_2014-v_anglaise2.pdf

Douay, N., 2009. L'émergence des politiques métropolitaines marseillaises: entre conflits et apprentissages. Cybergeo: European Journal of Geography, document 459. doi: $10.4000 /$ cybergeo.22347

Drobenko, B., 2013. Entre écosystèmes et territoires : quelle planification pour les espaces relevant de la GIZC ?. VertigO- la revue électronique en sciences de l'environnement, Hors-Série 18. doi: 10.4000/vertigo. 14271

Dubois-Maury, J., 2010. Documents d'urbanisme et développement durable. Editions du Puits Fleuri. $414 \mathrm{pp}$. 
EEA, 2006a. Land accounts for Europe 1990-2000. Towards integrated land and ecosystem accounting. European Environment Agency, Copenhagen, EEA Report, 11, 107 pp. http://www.eea.europa.eu/publications/eea_report_2006_11

EEA, 2006b. The changing faces of Europe's coastal areas. European Environment Agency, Copenhagen, EEA Report 6, 107 pp. http://www.eea.europa.eu/publications/eea_report_2006_6

Gangai, I.P.D., Ramachandran, S., 2010. The role of spatial planning in coastal management - A case study of Tuticorin coast (India), Land Use Policy, 27, 518-534. doi:10.1016/j.landusepol.2009.07.007

Gould, P., 1970. Computers and spatial analysis: Extensions of geographic research, Geoforum, 1, 1, 53-69. doi:10.1016/0016-7185(70)90006-0

Goze, M., 1999. La loi d'orientation foncière: de la croissance urbaine à la métropolisation. In: Annuaire des collectivités locales. 19, 1, 101-121. URL: http://www.persee.fr/doc/coloc_02914700_1999_num_19_1_1331

Grandclément, $\bar{A}_{\text {., Boulay, }}$. ., 2015. Fonction résidentielle et dynamique de la fiscalité locale sur le littoral méditerranéen français, L'Espace Géographique, 44, 1, 57-72.

Guneroglu, A., 2015. Coastal changes and land use alteration on Northeastern part of Turkey. Ocean \& Coastal Management, 118, Part B, 225-233. doi:10.1016/j.ocecoaman.2015.06.019

Haggett, P., 1965. Locational analysis in Human Geography. Arnold, London, 339 pp. Revised edition in 1977.

IAU-IDF, 2010. Les démarches Inter-Scot en France État des lieux en 2009 et perspectives. Institut d'Aménagement et d'Urbanisme d'lle de France, Paris, $121 \mathrm{pp}$. URL : https://f.hypotheses.org/wpcontent/blogs.dir/200/files/2015/06/93CONSTANTY_2010a.pdf

Janßena, H., Kiddb, S., Kvingec, T., 2013. A spatial typology for the sea: A contribution from the Baltic. Marine Policy, 42, 190-197. doi: 10.1016/j.marpol.2013.03.001

Lebahy, H., Le Délézir, R., 2006. Le littoral agressé. Pour une politique volontariste de l'aménagement en Bretagne. Editions Apogée, Rennes, 190 pp.

Levin, N., Elron, E., Gasith, A., 2009. Decline of wetland ecosystems in the coastal plain of Israel during the 20th century: Implications for wetland conservation and management. Landscape and Urban Planning, 92, 220-232. doi:10.1016/j.landurbplan.2009.05.009

Longley, P. A., Cheshire, J. A., Mateos, P., 2011. Creating a regional geography of Britain through the spatial analysis of surnames. Geoforum, 42, 4, 506-516. doi:10.1016/j.geoforum.2011.02.001

Malvárez Garcia, G., Pollard,J., Domínguez Rodriguez, R., 2003. The planning and practice of coastal zone management in Southern Spain. Journal of Sustainable Tourism, 11, 204-223. doi: $10.1080 / 09669580308667203$

Crozet, S. (Ed.), 2010. Outils juridiques pour la protection des espaces naturels. Ministère de l'Ecologie et du développement durable, GIP Atelier technique des espaces naturels, Délégation à l'aménagement du territoire et à l'action régionale, Ministère des transports, de l'équipement, du tourisme et de la mer, Office national des forêts, Conservatoire de l'espace littoral et des rivages lacustres, Ministère de l'agriculture et de la pêche, Paris. Cahiers techniques $n^{\circ} 78$. URL: http://ct78.espaces-naturels.fr/

Meinesz A., Lefevre, J.R., Astier J.M., 1991. Impact of coastal development on the infralittoral zone along the southeastern Mediterranean shore of continental France. Marine Pollution Bulletin, 343347. doi:10.1016/0025-326X(91)90698-R

Melot R., Paoli J.C., 2011. Conflits et règles d'utilisation des espaces littoraux : le cas de la Corse. In: Elloumi, M., Jouve, A.M., Napoléone, C., Paoli, J.C. (Eds.), Régulation foncière et protection des terres agricoles en Méditerranée. CIHEAM, Montpellier. Options Méditerranéennes: Série B. Etudes et Recherches; 66, 115-126. URL: http://om.ciheam.org/om/pdf/b66/b66.pdf

Merckelbagh, A., 2009. Et si le littoral allait jusqu'à la mer ! La politique du littoral sous la Vè République, Quae, Versailles, $351 \mathrm{pp}$.

Newman, P., Thornley, A., 1996. Urban Planning in Europe: International Competition, National Systems and Planning Projects. Routledge, $304 \mathrm{pp}$.

Pelenc, J., 2014. Développement humain responsable et aménagement du territoire. Réflexions à partir de deux réserves de biosphère périurbaines en France et au Chili (Doctoral thesis). Université de la Sorbonne nouvelle, Paris III. 481 pp. URL: https://tel.archives-ouvertes.fr/tel-00993203

Perrin, C., (Ed.), 2013. Un littoral sans nature? L'avenir de la Méditerranée face à l'urbanisation. Ecole Française de Rome, Rome, $345 \mathrm{pp}$.

Petrov, L., Lavalle, C., Kasanko, M., 2009. Urban land use scenarios for a tourist region in Europe: applying the MOLAND model to Algarve, Portugal. Landscape and Urban Planning, 92, pp. 10-23. doi:10.1016/j.landurbplan.2009.01.011 
Piquard, M., 1974. Perspectives pour l'aménagement : le littoral français. La Documentation Française, Paris, $268 \mathrm{pp}$.

Poelmans, L., Van Rompaey, A., 2009. Detecting and modelling spatial patterns of urban sprawl in highly fragmented areas: A case study in the Flanders-Brussels region. Landscape and Urban Planning, 93, 10-19. doi:10.1016/j.landurbplan.2009.05.018

Pons, A., Rullan, O., 2014. The expansion of urbanisation in the Balearic Islands (1956-2006). Journal of Marine and Island Cultures, 3, 78-88, doi:10.1016/j.imic.2014.11.004

Priet, F., 1992. La décentralisation de l'urbanisme - Bilan et perspectives. In: Annuaire des collectivités locales, 12, 87-107. URL : http://www.persee.fr/doc/coloc_0291-4700_1992_num_12_1_1113

Robert, S., 2016. Entre étalement et densification: une approche fine de l'urbanisation littorale sur la Côte bleue, Provence. Cybergeo : European Journal of Geography, document 764. doi: 10.4000/cybergeo.27451

Robert, S., Prévost, A., Fox, D., Trémélo, M-L., Pasqualini, V., 2015. Coastal Urbanization and Land Planning in Southern France. In: Özhan, E. (Ed.). Proceedings of the Twelfth International Conference on the Mediteranean Coastal Environment, MEDCOAST 15, 1-2, 119-130.

Rochette, J., 2007. Le traitement juridique d'une singularité littorale: La zone côtière, étude en droit international et en droit comparé franco-italien, Université de Nantes, (Doctoral thesis), 810 pp. French. URL: https://tel.archives-ouvertes.fr/tel-00172410

Romano, B., Zullo, F., 2014. The urban transformation of Italy's Adriatic coastal strip: Fifty years of unsustainability. Land Use Policy, 38, 26-36. doi:10.1016/j.landusepol.2013.10.001

Silk, J., 1979. Statistical concepts in Geography. George Allen and Unwin, London.

SOeS-ONML, 2009. Occupation du sol dans les communes littorales en 2006 et évolution depuis 2000. Observatoire du Littoral, Rédaction SOeS, Version 2, 7 pp. URL: http://www.onml.fr/onml_f/fiches/occupation_du_sol_dans_les_communes_littorales_en_2006_et evolution_depuis_2000/sol_communes.pdf

SOeS, Agence des aires marines protégées, Ifremer et Cerema (DT Méditerranée). 2014. Les données clés de la mer et du littoral. Synthèse des fiches thématiques de l'observatoire. $59 \mathrm{pp}$. URL: http://www.onml.fr/uploads/media/document_01.pdf

Sparfel, L., Le Berre, I., Gourmelon, F., 2011. Évaluation des changements d'occupation des sols en zone côtière à partir de données hétérogènes. European Journal of GIS and Spatial Analysis / Revue Internationale de Géomatique, 21 (3), 381-403. doi:10.3166/rig.15.381-403

Su, W., Gu C., Yang, G., Chen, S., Zhen, F., 2010. Measuring the impact of urban sprawl on natural landscape pattern of the Western Taihu Lake watershed, China. Landscape and Urban Planning, 95, 61-67. doi:10.1016/j.landurbplan.2009.12.003

Swerts, E., Pumain, D., 2013. Approche statistique de la cohésion territoriale : le système de villes en Inde. L'Espace géographique, 42, 1, 75-90. URL : www.cairn.info/revue-espace-geographique2013-1-page-75.htm

Tafani, C., 2010. Littoral corse: entre préservation de la nature et urbanisation, quelle place pour les terres agricoles?, Méditerranée, 115. URL: http://mediterranee.revues.org/5216

Tang, Z., 2008. Evaluating local coastal zone land use planning capacities in California. Ocean \& Coastal Management, 51, 7, 544-555. doi :10.1016/j.ocecoaman.2008.06.001

Taylor, P., 1977. Quantitative methods in Geography: an Introduction to Spatial Analysis. Waweland Press, Prospect Height, IL, 386 pp.

Vallega, A., 1995. Towards the sustainable management of the Mediterranean Sea. Marine Policy, 19, 1, 47-64. doi: http://dx.doi.org/10.1016/0308-597X(95)92572-O

Volle, J.-P., 1985. Montpellier en Languedoc-Roussillon : la logique de la Capitale. Etudes Héraultaises, 1,12 pp. URL : https://www.etudesheraultaises.fr/montpellier-logiquecapitale-882/

Zaninetti, J-M., 2006. Urban sprawl in France. A regional typology of urbanization trends and its demographic and economic background. Bulletin of Geography. Socio-economic Series, (5), 5-20. 